\title{
Indirect Effects of Introduced Predators on Seabird Islands
}

\author{
J.C. Russell
}

\section{Introduction}

The Farallon Islands, $35 \mathrm{~km}$ west of San Francisco, are home to the largest, most diverse seabird assemblage in the continental United States, including 50\% of the world population of Ashy storm petrel (Oceanodroma homochroa), which breeds here over the summer. From 1972 to 1992, the storm petrel population on Southeast Farallon Island declined by $34 \%$. Cats, rabbits, and mice were all introduced to the Farallon Islands, but the cats and rabbits had been removed in the 1970s. Although mice are not significant predators of the Ashy storm petrel, migratory burrowing owls (Athene cunicularia) arrive in the autumn, corresponding with the seasonal irruption of mice. After staying a few days to feed on mice, most burrowing owls return to the mainland, but a small number are able to over-winter. These remaining owls then diet-switch to Ashy storm petrels, which arrive prospecting for new sites at the start of spring. Owls have a significant impact on the seabird's population viability. Thus, although mice do not directly impact the Ashy storm petrel, they have a strong indirect effect through the burrowing owl.

Conservation managers are primarily concerned with the often severe and obvious direct effects of predators on island biota, where the introduced predator decreases the abundance of its prey species (Schoener and Spiller 1996, Krajick 2005). The introduction of seabird predators to seabird islands has had major impacts upon island communities, impacting prey communities directly through consumption (Chapters 2, 3, and 4) as well as plants and consumers through the removal of seabird impacts such as nutrient additions and physical disturbance (Chapters 5, 6, and 7). However, as the above example illustrates, introduced predators can also generate indirect interactions, either via the changes they impose on community structure and trophic interactions, or when the introduced predators are removed during restoration (Chapters 10 and 11). The focus of this chapter will be the indirect effects of introduced predators on other animal species, both native and introduced, that alter the outcomes of trophic and competitive interactions. The possibility of indirect and complex interactions arising from either the introduction or removal of a non-native predator should be considered when planning for the eradication of predators and subsequent restoration of seabird islands. 
Although introduced seabird predators include species from many taxonomic groups (Chapter 3), the vast majority can be classified into one of three categories depending on their trophic position (see Chapters 3 and 4 for details on specific species; Figure 9.1, shaded boxes). A top predator is the highest order, or apex, predator in a food chain. Mesopredators are any other middle-ranking predatory species in a food chain (Prugh et al. 2009). A mesopredator in one system may become the top predator in another, if it becomes the highest-order predator. On seabird islands, introduced top predators and mesopredators may be distinguished by other biological characteristics (Chapter 4). However, the types of indirect interactions that occur depend not just on the trophic position of the introduced species (O'Connor and Crowe 2005), but also on the composition of the animal community (including other introduced species) and on island characteristics such as island size, climatic conditions, seasonality, and human history. These two sets of factors are not independent, with island characteristics affecting the community composition on an island. Global variation in animal community and island identity means that generalizations about indirect effects on island communities are likely to remain elusive. Consider the three introduced rat species, Rattus exulans, $R$. norvegicus, and $R$. rattus, that are now present on over $80 \%$ of the world's island groups: their role as predators varies greatly based on the community composition of vulnerable species and island biogeography driving population dynamics (Towns et al. 2006). On Northeast New Zealand islands and on Cook Strait islands, rats are often the highest-order predators, and can impact seabird populations (Gaze 2000, Pierce 2002) as well as other species (Towns 1991, Campbell and Atkinson 2002). In contrast, on the Falkland Islands, rats provide a food source for larger introduced predators such as cats (Catry et al. 2007, Quillfeldt et al. 2008), while on the French Mediterranean islands, where rats have co-occurred with seabirds for more than a thousand years, their current negative impacts on seabirds are primarily through competition for burrows (Ruffino et al. 2008). The role of introduced predators within a food web can, therefore, depend very much on ecological context.

\section{Three-way Interactions}

When only three interacting species are considered, five different predator-related indirect effects are possible, depending on the trophic position of each species and interactions among them (Figure 9.2). I will illustrate each of these interactions using seabird island examples before discussing the more complicated situations that arise when more than three species or groups interact.

\section{INTERSPECIFIC COMPETITION}

Interspecific exploitative competition (Figure 9.2a) can occur when two species interact via a shared resource, such as food or breeding sites. On islands, multiple introduced seabird predators that share many prey species are often present. 


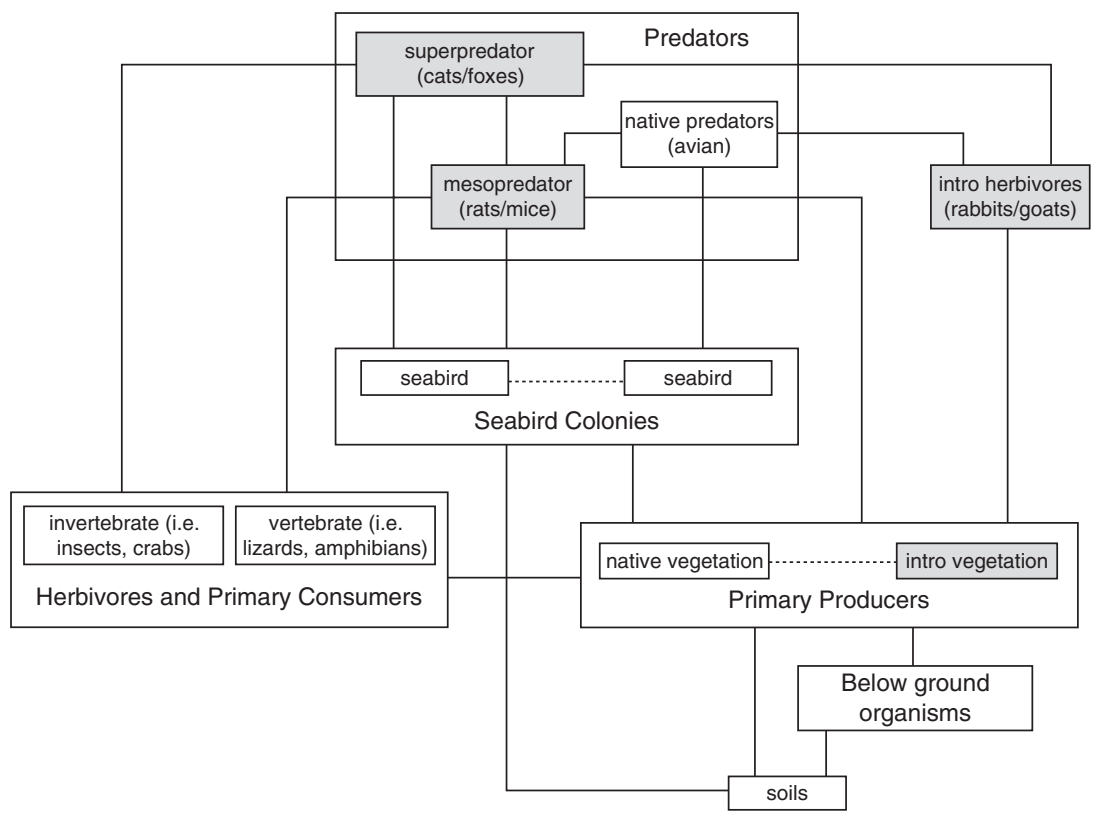

FIGURE 9.1 Simplified seabird island food web. Shaded boxes include taxa and feeding guilds of introduced, invasive species that can potentially change the interactions among the native species.

a) Interspecific Competition $\quad$ b) Apparent Competition

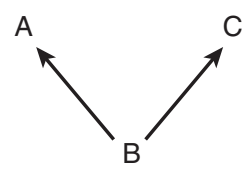

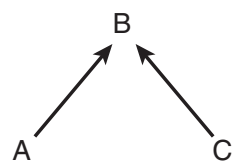

c) Trophic Cascade

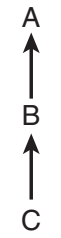

d) Symmetrical Intraguild Predation

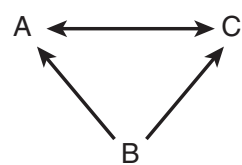

d) Asymmetrical Intraguild Predation

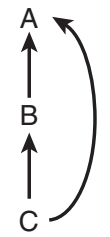

FIGURE 9.2 Indirect three-species interactions (following Wootton 1994) including intraguild predation (Polis et al. 1989). Arrows indicate direction of energy flow. 
For example, on islands off of southern New Zealand, an introduced rail (Gallirallus australis) competes with introduced rats ( $R$. rattus) for petrel (Puffinus griseus) chicks (Harper 2007). In Western Australia, introduced cats (Felis catus) and red foxes (Vulpes vulpes), both considered "superpredators" (Chapter 3), are also likely to engage in strong competition where they coexist (Risbey et al. 1999). Competition between two introduced species may be stronger when they have similar functional identities, although two functionally distinct predators may share the same prey species but at different prey life stages. Predation by two different predators upon a prey species increases the probability of prey extinction. Prey may be able to find refuge from one predator but not from a second, functionally different predator that preys upon an otherwise protected prey state (e.g., an alternative life stage), so the probability of refugia existing for a prey population is greatly diminished (Krivan 1998, Sih et al. 1998, Blackburn et al. 2005, Orrock et al. 2010).

Competition between two introduced species may also be asymmetrical, with one species less negatively affected than the other (Persson 1985). For example, on New Zealand islands where both rats (Rattus spp.) and mice (Mus musculus) are present, rats often suppress mouse populations to very low levels. This can lead to undesirable results when only one species is the target of a control or eradication operation. For example, the removal of rats has resulted in a large and rapid increase in the mouse population on multiple occasions (Caut et al. 2007).

Introduced predators can also compete with native species, although competition as a cause of native species decline is more difficult to detect than the impacts of predation (Davis 2003). On Canna Island in the Inner Hebrides, Scotland, introduced cats and reintroduced native sea eagles (Haliaeetus albicilla) compete for both native and introduced prey (see Box 9.1). Competition among omnivores can be for other food resources besides prey. Introduced rodents can have negative effects on native small mammals, and although the mechanism is not always clear, resource competition is likely (Harris 2009, Harris and Macdonald 2007). The consumption of vegetation and seeds by introduced rodents also generates resource competition with other species, such as forest birds (Moles and Drake 1999, Graham and Veitch 2002). This ultimately leads to indirect alteration of forest communities, with some species benefiting and others not (Campbell and Atkinson 2002; Chapter 4).

Introduced species can also compete directly with seabirds for resources other than food. For example, on islands in the French Mediterranean, introduced rats ( $R$. rattus) compete with Yelkouan shearwaters (Puffinus yelkouan) for available burrows(Ruffino et al. 2008), and on theChannel Islands in California, introduced grazing mammals interfere with seabird nesting success by destroying breeding sites (McChesney and Tershy 1998).

\section{APPARENT COMPETITION}

Apparent competition can occur when a predator has two or more sources of prey available (Holt 1977, Holt and Lawton 1994). Changes in the abundance of one prey may alter the abundance or behavior of the predator, and affect the predator's 


\section{Conservation Objectives with Multiple Species Interactions}

\section{Location: Canna Island, Inner Hebrides, Scotland Climate: Wet temperate}

Multiple conservation objectives, such as the conservation priority of different species, can complicate management interventions and strategies. Canna Island (1126 ha), an island off the northwest coast of Scotland that is heavily farmed, is now being managed for natural and historic heritage. Norway rats, which posed a threat to resident seabirds and to a species of wood mouse (Apodemus sylvaticus), were eradicated. White-tailed sea eagles (Haliaeetus albicilla) have been reintroduced to Scotland, and two pairs breed on Canna Island, where approximately $54 \%$ of their diet is introduced rabbits. Canna Island also has feral cats and hedgehogs (Erinaceus europaeus), both of which may prey directly upon seabirds and other ground-nesting species. Currently, cats heavily rely upon rats and rabbits for food, so the removal of rats may counterproductively increase predation of rabbits by cats, creating a competitive disadvantage for the sea eagles, which are one of the target species for conservation. Furthermore, without rats, there is a potential for cats to switch to heavier predation of wood mice, or the seabirds that also form part of the diet of sea eagles (A. Patterson, personal communication).

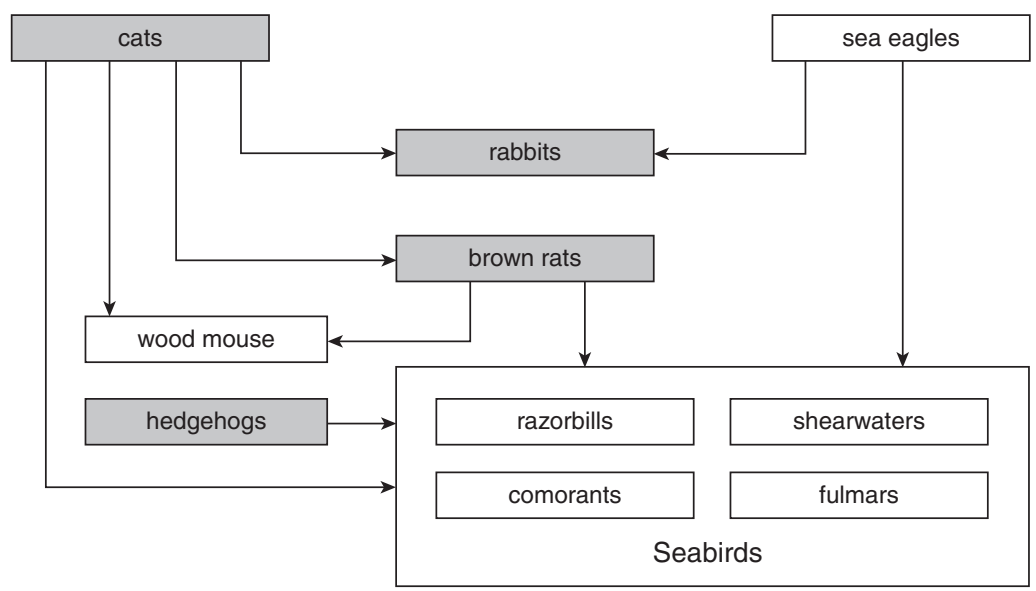

Complex food web on Canna Island, Scotland, showing competitive and predatory relationships among multiple introduced (grey boxes) and native (white boxes) taxa. Management strategies must monitor possible mesopredator releases and effects of direct and apparent competition.

impact on all other prey in the system. For example, rats (Rattus rattus) on Surprise Island, New Caledonia, preferentially switch prey between seabird chicks and green turtle (Chelonia mydas) hatchlings, each of which is available in different seasons. This prey switching by rats limits juvenile recruitment for both threatened species (Caut et al. 2008). Without considering the mediation by the predator, 
the two prey species may appear to be competing, hence the term apparent competition.

The dynamics of apparent competition on islands have been theoretically studied for the specific case where the primary prey is a native species, and the predator and secondary prey are introduced mammals (Courchamp et al. 1999, Gaucel and Pontier 2005, Zhang et al. 2006). An introduced prey species evolutionarily adapted to mammalian predation via a high growth rate can facilitate an increase in abundance of the introduced predator. For example, introduced mammalian predators such as cats most commonly prey upon small, introduced mammals such as rabbits and rodents, as well as on native seabirds. Because rabbits and rodents have coevolved with such mammalian predation, they are subject to lower attack rates than native island species such as birds or reptiles. In the extreme case, this may lead to the local extinction of the native prey via a process termed hyperpredation (see Box 9.2). Widespread empirical evidence suggests that apparent competition leads to hyperpredation on islands around the world. For example, golden eagle (Aquila chrysaetos) colonization of the Channel Islands off the California coast, United States, was facilitated by the introduction of pigs (Sus scrofa), leading to a decline in island foxes (Urocyon littoralis; Roemer et al. 2002). Although a top predator may persistently consume multiple prey species, including introduced prey, hyperpredation leading to local extinction does not always occur. How predators interact with introduced prey will depend on community composition and system regulation. The presence of strong territoriality or interference competition among predators can dampen the risk of hyperpredation. For hyperpredation to occur, the presence of an alternative prey must lead to an increased impact of the predator on the prey of conservation concern, usually via an elevated density of the predator. In particular, the presence of alternative prey is commonly linked to greater impacts of introduced predators on native prey (Donlan and Wilcox 2008).

In many locations, particularly in temperate zones, breeding seabirds are only present on islands during part of the year (Chapter 2). If predator populations crash during the season when seabirds are absent, rather than switching to alternative prey, seabird populations may retain a positive growth rate ("predator swamping") despite the presence of their predators (Taylor 1979b, Catry et al. 2007, Peck et al. 2008). The time lag for seabird predators to experience a numerical response to high prey availability during seabird nesting season protects the seabird population from strong predator control. If an introduced species that was an important prey species is eradicated, predators may permanently shift to another prey type (Box 9.1). However, this does not always occur. For example, on Stewart Island, New Zealand, when introduced rodents were eradicated, cats did not switch to native forest birds as prey, but rather declined in proportion to rat abundance (Harper 2005).

The presence of introduced prey can also interfere with attempts to biologically control introduced predators through the additional introduction of their predators or pathogens (Holt and Hochberg 2001). Introduced prey with high growth rates may be able to subsidize introduced biological control agents, thus allowing the agents to maintain high densities, which can lead to unintended 


\section{Single Species Removals and Hyperpredation}

\section{Location: Macquarie Island, Southern Ocean, Australia Climate: Subantarctic}

Indirect effects of single species introductions and/or removals can lead to cascading impacts throughout island ecosystems, but the exact pathways may be unclear and difficult to establish and quantify. On subantarctic Macquarie Island $(12,785$ ha) in the Southern Ocean, multiple mammal species introductions have drastically altered the ecosystem. Historically, cats and the endemic Macquarie Island parakeet (Cyanoramphus erythrotis) coexisted for nearly 70 years. However, within 10 years of the introduction of rabbits in 1879 , the parakeet went extinct, presumably due to hyperpredation by cats, which were subsidized by rabbits (Taylor 1979a). Many years later, rabbits were controlled to protect the island's native vegetation through the release of a Myxoma virus. Unfortunately, this led to cats diet-switching from rabbits to seabirds, so managers began controlling cats, and eventually eradicated them (Copson and Whinam 2001). Since cats were eradicated in 2001, rabbits have once again increased in numbers (Bergstrom et al. 2009), although it is unclear whether this release is attributable to the cessation of cat predation or the decrease in efficacy of viral control (Dowding et al. 2009). Vegetation cover has also decreased with rebounding rabbit density, although this effect is confounded by climate warming over the past 50 years. These changes in vegetation may further be affecting introduced rodent and seabird habitat. The number and complexity of relationships within this heavily invaded system require that a whole-ecosystem perspective remain paramount for the successful restoration of the island, where additional introduced species are continually discovered (e.g., Greenslade et al. 2007).

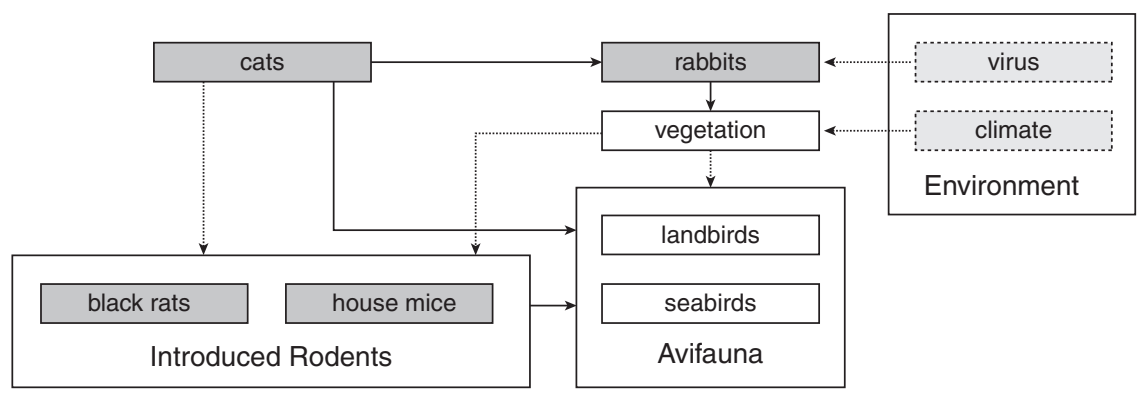

Biological control of introduced rabbits on Maquarie Island, south of Australia, stimulated hyperpredation of introduced cats on native land birds and seabirds. Subsequent control and eradication of cats then released rabbits from control by both cats and Myxoma virus, which then contributed to decreases in island vegetation.

negative impacts on native alternative prey. Predators with intermediate levels of control are able to maintain the highest densities. The failure of biological control through introductions of mammalian predators is evident: a native alternative prey with lower intrinsic growth rates (e.g., seabirds) that is subjected to higher attack rates faces a much greater risk of extinction. 


\section{TROPHIC CASCADES}

In a trophic cascade, population increases at higher trophic levels reduce populations of prey at the next lower trophic level, which in turn leads to increases at the next trophic level, and so on. The introduction of high-level predators to islands around the world has led to many native species extinctions, in turn leading to changes in the populations of their prey (Blackburn et al. 2004, Towns et al. 2006; also Chapter 3). On small islands in the Bahamas, the experimental introduction of brown anole lizards (Anolis sagrei) as both a predator and competitor of web-building spiders led to indirect changes in spider and insect abundance, leaf damage, and hymenopteran parasitoids (Schoener and Spiller 1999). On Christmas Island, (Indian Ocean) the invasion of yellow crazy ants (Anoplolepis gracilipes) locally eliminated red land crab populations, releasing dense plant communities across the island (O'Dowd et al. 2003). However, because most seabirds feed at sea, not on land, the presence of seabird predators does not usually lead to trophic cascades on islands, but rather to changes in nutrient inputs and subsequent changes in primary and secondary productivity (see Chapter 7). Exceptions include cases where the seabird species consume some terrestrial fauna. For example, on islands invaded by rats in the Aleutians, the loss of glaucous-winged gulls (Larus glaucescens) and black oystercatchers (Haematopus bachmani) releases their intertidal invertebrate prey, consequently decreasing algal cover upon which the invertebrates fed (Kurle et al. 2008).

\section{INTRAGUILD PREDATION}

Intraguild predation occurs when two predators are simultaneously involved in predatory and competitive relationships with one another (Polis et al. 1989). If the two predators both prey upon and compete with one another, such as two species of introduced rat, this is symmetrical intraguild predation. If only one predator (i.e., a top predator) preys upon another predator (i.e., a mesopredator), such as cats and rats, this is asymmetrical intraguild predation. Intraguild predation is particularly common among opportunistic introduced predators, which usually have high diet plasticity.

When intraguild predation occurs, the dominant relationships among the two predator species and their shared prey species will determine the exact nature of the indirect interaction. Symmetrical intraguild predation is uncommon among introduced predators, even when they occupy the same trophic level (Gerber and Echternacht 2000). When asymmetry dominates, and both predators have a substantial impact upon the shared prey, a mesopredator release effect may occur upon removal of the top predator. Although mesopredator release effects have been repeatedly emphasized in the island conservation literature, there are few documented examples (Zavaleta et al. 2001, Bull and Courchamp 2009). On Little Barrier Island in New Zealand, cats and rats (Rattus exulans) both preyed upon petrels (Pterodroma cookii), although the cats also preyed upon the rats. Following cat eradication, breeding success of the petrels dropped 
substantially, and only recovered after rat eradication (Rayner et al. 2007). Rats are likely to have driven this reduction in petrel breeding success; however, evidence of an increase in rat abundance after cat eradication is lacking (Girardet et al. 2001). Furthermore, although breeding success declined following cat eradication, an unmeasured increase in adult seabird survival was also likely, and so the overall effect on the seabird population growth rate remains unknown (LeCorre 2008).

When the top predator has a much greater impact upon the shared prey, the mesopredator will function more as an alternative prey for the top predator, shifting system dynamics to hyperpredation and apparent competition. On Tatoosh Island, Washington, peregrine falcons (Falco peregrinus) directly reduce the abundance of some seabird species, but through their predation on crows (Corvus caurinus) release other seabird species from crow predation on their eggs (Paine et al. 1990). This change in dominant indirect interaction also coincides with a shift from top-down regulation in systems where mesopredators are released, to bottom-up regulation in systems where hyperpredation occurs. The outcome of intraguild predation will, therefore, depend most strongly on the predation mechanism and the strength of the mesopredator impacts on its prey.

Cats have been eradicated from several islands where rats have remained with seasonally breeding sooty terns (Onychoprion fuscatus), but rats were simultaneously controlled during and after these cat eradications, preventing an experimental test of the mesopredator release effect. On Isla Isabela (194 ha) in Mexico, adult survival of sooty terns increased following cat removal, and rat abundance only increased briefly following eradication (Rodríguez et al. 2006). On Ascension Island in the South Atlantic, adult survival of sooty terns also increased following cat eradication, but although rat (Rattus rattus) abundance did not change, their predation on tern chicks increased following cat removal. Nonetheless, the tern population recovered with a positive growth rate (Hughes et al. 2008). Conversely, bald eagles (Haliaeetus leucocephalus) directly reduced the abundance of adult common murres (Uria aalge) and facilitated crow predation on common murre eggs when eagles flushed adult murres from their nests (Parrish et al. 2001).

\section{MUTUALISMS}

Mutualisms occur when two species are engaged in an interaction of benefit to both (Boucher et al. 1982). Such relationships often involve tightly coupled, coevolved species pairs, such as plant reproductive relationships mediated by pollinators and dispersers (Kearns et al. 1998). Many insular plant species are dependent upon a small number of coevolved mutualisms, although pollinators and dispersers can themselves interact with a larger number of species (Olesen et al. 2002). If a mutualism is disrupted by an introduced species, this can affect one or both species (Bond 1994), with the possibility of cascading indirect effects upon other species within a community. Introduced predators are a common cause of mutualism breakdown on islands, through their direct effect upon species participating in mutualisms (Kelly et al. 2006). 
Because of the reduced taxonomic diversity on many remote islands, a result of limited colonizations followed by adaptive radiations (Gillespie et al. 2008), mutualisms on islands have less redundancy where other species would be able to continue the mutualism should one species fail. For plant-pollinator mutualisms, the loss of coevolved avian pollinators to introduced predators has meant that many plant species fall below a threshold for viable population recruitment (Traveset and Richardson 2006). Examples of this include honey-eaters and mistletoe (Peraxilla spp.) in New Zealand (Robertson et al. 1999), and Drepanidinae birds and Lobelioideae plants in Hawaii (Lammers and Freeman 1986).

Introduced predators can also disrupt plant-dispersal mutualisms, by eliminating plant dispersers such as fruit-eating birds (Delgado-García 2002). In New Zealand, the loss of large avian seed dispersers means large-fruited plants now have reduced dispersal (Clout and Hay 1989). In the Balearic Islands, Spain, the loss of endemic lizards (Podarcis spp.) to introduced carnivores has resulted in reduced dispersal of Cneorum tricoccon (Cneoraceae; see Riera et al. 2002). In some cases, introduced species may replace other species in mutualisms, or create new ones (Chapter 4). Introduced rodents usually destroy seeds during predation, but can also disperse them (Williams et al. 2000, Grant-Hoffman and Barboza, 2010). This mutualism can extend to introduced plant species, leading to an invasional meltdown (Simberloff and Von Holle 1999, Simberloff 2003, Bourgeois et al. 2005). For example, in the Balearic Islands, Spain, the presence of $R$. rattus increases the dispersal of ice plants (Carpobrotus spp., Aizoaceae; Traveset et al. 2009). Ice plants in turn impact other plants species by increasing soil salinity (D’Antonio and Mahall 1991). These shifts in seed predation and dispersal mutualisms ultimately lead to changes in community composition, such as succession to forest communities on islands (Campbell and Atkinson 2002). Generally, introduced animals do not substitute for native species in mutualisms (Olesen et al. 2002), or they are a poor substitute (Kelly et al. 2006).

\section{MULTIPLE SPECIES}

Introductions of multiple exotic species are typical for most islands. The presence of multiple introduced species presents complex and often competing scenarios for conservation managers considering species removals (Courchamp et al. 2003, Box 9.1, Box 9.2). On Tatoosh Island, Washington, peregrine falcons (Falco peregrinus) directly reduce the abundance of Cassin's auklets (Ptychoramphus aleuticus) and rhinoceros auklets (Cerorhinca monocerata), but through their predation on crows (Corvus caurinus) they release common murres and pelagic cormorants (Phalacrocorax pelagicus) from crow predation on eggs (Paine et al. 1990). Plausible hypotheses for indirect interactions (Bergstrom et al. 2009) can be confounded by other processes, both biotic and abiotic, operating from within and outside of these systems (Dowding et al. 2009). Shifts between indirect interactions among many species will depend heavily on the mode of system regulation or other externally driven changes to systems. Resources pulses, such as rainfall or mast seeding events, can stimulate bottom-up controls that quickly translate into 
numerical increases in predators, thus allowing predators to temporarily exert a significant top-down control on lower trophic levels (Sears et al. 2004, Ruscoe et al. 2006). New species introductions can also mediate new indirect interactions. The introduction of pigs (Sus scrofa) to California Channel Islands caused the entire system to shift from competition between native foxes (Urocyon littoralis) and spotted skunks (Spilogale gracilis amphiala) to predation by introduced bald eagles (Aquila chrysaetos), which were subsidized by pigs, upon the native foxes (Roemer et al. 2002).

\section{Implications for Restoration}

Indirect interactions are a prominent concern in conservation management literature (Zavaleta et al. 2001, Courchamp et al. 2003, Doak et al. 2008). Models have hypothesized where and how indirect interactions may occur (Courchamp and Caut 2006), and real examples of these have been observed following invasions or conservation interventions (Box 9.2). A minimal understanding of how species interact within an ecosystem prior to conservation intervention can prevent future "surprises," and baseline research can go a long way to provide this information (Box 9.3). However, conservation interventions may have some urgency where species extirpation or invasion is imminent, so conservation management must depend on a judicious blend of research and direct action (Simberloff 2003). Management of multiple introduced predators requires a whole ecosystem context (Zavaleta et al. 2001; Chapter 11), primarily because the relationships among introduced predators and other introduced species are themselves not clearly defined (e.g., intraguild predation). Guidelines are available for managing introduced species where indirect interactions are known to be likely (Bull and Courchamp 2009).

While theoretical models can inform conservation and restoration efforts on islands, many models focus on equilibrium dynamics. Dynamics during transient non-equilibrium phases, such as periods soon after predator introductions or eradications, may not be adequately represented by such equilibrium dynamics. This is particularly important when considering species coexistence. If an introduced predator and prey cannot coexist, then equilibrium conditions are not applicable. In this regard, a manager must distinguish between true species coexistence (in the equilibrium sense over infinite time) and persistence (coexistence, possibly long term, but only during transient shifts between equilibrium states).

The likelihood of an indirect effect following a species introduction or extirpation will depend on the nature of the trophic relationships, which depend on any or all of the individual species present, the community composition, and island biogeography factors. The presence of a particular species does not necessarily mean that a particular indirect interaction will occur. Evidence must be collected that the interacting species manifest a particular indirect effect, including alteration of growth rates, reproductive success, adult survival, and consequential changes in prey population size. Diet studies or even stable isotope studies alone 
BOX 9.3

\section{Baseline Research as a Prerequisite to Successful Management}

\section{Location: Surprise Island, Entrecasteaux Reef, New Caledonia Climate: Dry coral atoll}

Baseline research on island community food webs, especially that focusing on the trophic position and interactions of introduced mammals, can play an important role in developing appropriate management strategies. Surprise Island (24 ha) lies northwest of New Caledonia, and from 2002 to 2005 it was extensively studied by a multidisciplinary team of scientists in order to fully understand the trophic position of introduced black rats ( $R$. rattus) in the ecosystem, prior to their eradication. A combination of classical diet and stable isotope studies were used to determine which species most strongly interacted with the black rats. These revealed an important seasonal shift in diet from one threatened taxa, seabirds, to another, green sea turtles, both of conservation concern (Caut et al. 2008). Baseline ecosystem studies also revealed a previously undocumented population of introduced house mice living in the center of the island. Eradication of the rat population alone may lead to a competitor release effect, as has happened often on many other islands, where mice are more difficult to eradicate and generate an explosion in house mice numbers (Caut et al. 2007). At the same time, resident ant fauna were also monitored to document the possibility of trophic releases further down the food web. In the end, a modified rodent eradication program that accounted for the presence of mice was successful in eradicating both species, allowing the team of scientists to monitor the ongoing changes in the ecosystem following introduced species removal (Caut et al. 2009).

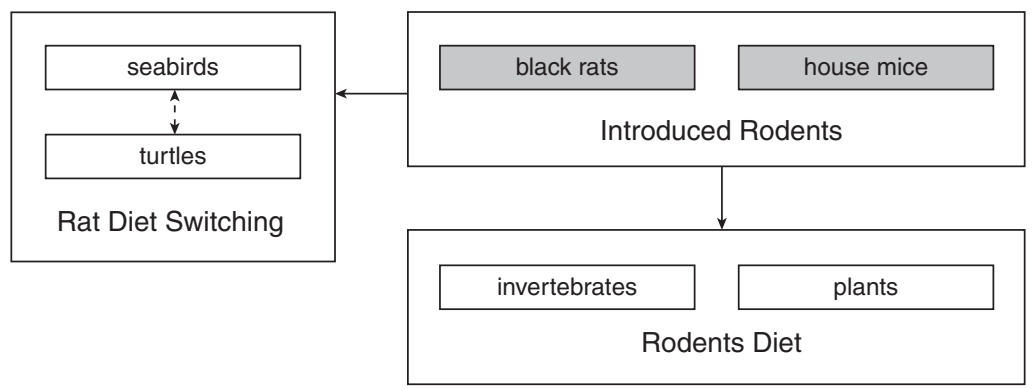

Baseline research on the dry atoll Surprise Island, northwest of New Caledonia, elucidated the complex diet behaviors of introduced ship or black rats (Rattus rattus) and uncovered the presence of a second introduced species, the house mouse (Mus musculus). Eradication and management strategies are on a successful trajectory with ongoing monitoring.

are not sufficient evidence in the absence of data on species densities and modes of system regulation. In predator studies, predator attack rates as well as prey growth rates must both be considered (Holt and Hochberg 2001). Because effects can be dependent on the identity of the predator, the island, or the community structure, prediction of indirect effects is difficult. Theoretical predictions will not work in all 
circumstances, and direct effects are quite likely to manifest themselves in most systems (Schoener and Spiller 1999, Spiller and Schoener 2001). Adaptive management is almost certainly required: managers must react to the most pressing conservation issues while preparing for unexpected future changes in system dynamics (Roy et al. 2009). Furthermore, relationships between predators and prey will also be modified by other environmental changes, such as physical changes to the habitat and changes in the climate (Schoener et al. 2001).

Many studies reporting indirect effects have only investigated a subset of components and population demographic parameters, possibly presenting a biased account of indirect effects. In order to reliably determine the occurrence of an indirect effect that affects conservation outcomes, data must show that relationships among species have not just an individual but a population-level effect. The presence of three interacting species does not in itself mean an indirect interaction of population-level consequence will occur among them. The effects among species must also consider all life-history stages, such as adult survival and reproductive success, thus giving an overall picture of the effect on population growth rate.

\section{Future Research}

An interest in indirect effects in island conservation has increased substantially over the last decade (Zavaleta et al. 2001, Courchamp et al. 2003, Doak et al. 2008). Much of the interest has arisen from mathematical models hypothesizing many potential indirect interactions following species introductions or removals. Other interest has come from observed unexpected changes in ecosystems following species removals. A large gap remains between matching theoretical predictions to observed outcomes following conservation intervention. Only recently have species eradications been used as true experimental tests of model predictions, such as for trophic cascades (Fukami et al. 2006). The relative strength and direction of indirect versus direct effects on conservation targets requires quantification, so that conservation managers can employ conservation strategies even when baseline information is incomplete or not obtainable. The relative roles of top-down and bottom-up system regulation remain unclear, and require further investigation.

Now, with a basic understanding of indirect effects in island communities (Courchamp et al. 2003, Croll et al. 2005, Fukami et al. 2006), and the capacity to remove many introduced species completely from islands (Nogales et al. 2004, Clout and Russell 2006, Howald et al. 2007, Chapter 10), it should be possible to propose methods and approaches for restoring the ecological functioning of islands, finally moving to the "whole island perspective" first proposed a decade earlier (Zavaleta et al. 2001; Chapter 11). Such an approach would require identifying community restoration trajectories following species eradications, and determining which functional groups are required to restore ecosystem processes. Seabirds are now clearly identified as a functional group that drives island ecosystems (Chapters 5, 6, and 7) and that require active conservation efforts to 
restore (Chapter 11). Other less conspicuous and currently unidentified species are also likely to be important.

A number of keystone species that are likely to contribute to indirect interactions remain understudied. These are predominantly species whose distribution or effects have been minor relative to previously highlighted species, whose eradication has not been possible, or that are difficult to study. Ants are emerging as an introduced species of concern, given that they are widespread, can have serious impacts, and are difficult to control (O’Dowd et al. 2003, Krushelnycky et al. 2005). Although not widely introduced, reptiles such as snakes (Savidge 1987) and amphibians (Estoup et al. 2001) can become dominant in ecosystems. Land crabs, although native, also play a major role in tropical ecosystems, and their effect on eradication efforts of other introduced species, and community dynamics in general, requires more investigation (Pain et al. 2000, O’Dowd et al. 2003).

Scientists and managers will have to work more closely together in the future, sharing results and identifying the relative tradeoffs required between study and intervention, in an effort to balance conservation goals and scientific understanding of island ecosystems. Meanwhile, in an ever-changing world, new indirect effects will continue to emerge and play a role in the ongoing processes of island ecosystems.

\section{Acknowledgments}

I would like to thank Matthieu Le Corre and Franck Courchamp for stimulating my interest in indirect interactions. Many of the ideas in this work were generated while working at the Universite de la Réunion on the French National Research Agency funded ALIENS project (ANR-05-BDIV-003-03). Don Croll and Robert Holt provided comments on earlier versions of the chapter. Figure 9.2 adapted and reprinted with permission from the Annual Review of Ecology, Evolution, and Systematics, Volume 25, (01994 by Annual Reviews.

\section{References}

Bergstrom, D.M., A. Lucieer, K. Kiefer, J. Wasley, L. Belbin, T.K. Pedersen, and S.L. Chown. 2009. Indirect effects of invasive species removal devastate World Heritage Island. Journal of Applied Ecology 46: 73-81.

Blackburn, T.M., P. Cassey, R.P. Duncan, K.L. Evans, and K.J. Gaston. 2004. Avian extinction and mammalian introductions on oceanic islands. Science 305: 1955-1958.

Blackburn, T.M., O.L. Petchey, P. Cassey, and K.J. Gaston. 2005. Functional diversity of mammalian predators and extinction in island birds. Ecology 86: 2916-2923.

Bond, W.J. 1994. Do mutualisms matter? Assessing the impact of pollinator and disperser disruption on plant extinction. Philosophical Transactions of the Royal Society of London B 344: 83-90.

Boucher, D.H., S. James, and K.H. Keeler. 1982. The ecology of mutualism. Annual Review of Ecology and Systematics 13: 315-347. 
Bourgeois, K., C.M. Suehs, E. Vidal, and F. Médail. 2005. Invasional meltdown potential: facilitation between introduced plants and mammals on French Mediterranean islands. Ecoscience 12: 248-256.

Bull, L.S., and F. Courchamp. 2009. Management of interacting invasives: ecosystem approaches. Pp. 232-247 in M.N. Clout and P.A. Williams, eds. Invasive species management: a handbook of techniques. Oxford University Press, Oxford.

Campbell, D.J., and I.A.E. Atkinson. 2002. Depression of tree recruitment by the Pacific rat (Rattus exulans Peale) on New Zealand's northern offshore islands. Biological Conservation 107: 19-35.

Catry, P., M.C. Silva, S. MacKay, A. Campos, J. Masello, P. Quillfeldt, and I.J. Strange. 2007. Can thin-billed prions Pachyptila belcheri breed successfully on an island with introduced rats, mice and cats? The case of New Island, Falkland Islands. Polar Biology 30: 391-394.

Caut, S., E. Angulo, and F. Courchamp. 2008. Dietary shift of an invasive predator: rats, seabirds and sea turtles. Journal of Applied Ecology 45: 428-437.

Caut, S., E. Angulo, and F. Courchamp. 2009. Avoiding surprise effects on Surprise Island: alien species control in a multitrophic level perspective. Biological Invasions 11: 1689-1703.

Caut, S., J.G. Casanovas, E. Virgos, J. Lozano, G.W. Witmer, and F. Courchamp. 2007. Rats dying for mice: modelling the competitor release effect. Austral Ecology 32: 858-868.

Clout, M.N., and J.R. Hay. 1989. The importance of birds as browsers, pollinators and seed dispersers in New Zealand forests. New Zealand Journal of Ecology 12 (supplement): 27-33.

Clout, M.N., and J.C. Russell. 2006. The eradication of mammals from New Zealand islands. Pp. 127-141 in F. Koike, M.N. Clout, M. Kawamichi, M. De Poorter, and K. Iwatsuki, eds. Assessment and Control of Biological Invasion Risks. IUCN, Gland, Switzerland and Cambridge, U.K., and Shoukadoh Book Sellers, Kyoto, Japan.

Copson, G., and J. Whinam. 2001. Review of ecological restoration progamme on subantarctic Macquarie Island: pest management progress and future directions. Ecological Management \& Restoration 2: 129-138.

Courchamp, F., and S. Caut. 2006. Use of biological invasions and their control to study the dynamics of interacting populations. Pp. 253-279 in M.W. Cadotte, S.M. McMahon, and T. Fukami, eds. Conceptual Ecology and Invasions Biology: Reciprocal Approaches to Nature. Springer, Dordrecht.

Courchamp, F., J.L. Chapuis, and M. Pascal. 2003. Mammal invaders on islands: impact, control and control impact. Biological Reviews 78: 347-383.

Courchamp, F., M. Langlais, and G. Sugihara. 1999. Control of rabbits to protect island birds from cat predation. Biological Conservation 89: 219-225.

Croll, D.A., J.L. Maron, J.A. Estes, E.M. Danner, and G.V. Byrd. 2005. Introduced predators transform subarctic islands from grassland to tundra. Science 307: 1959-1961.

D’Antonio, C.M., and B.E. Mahall. 1991. Root profiles and competition between the invasive, exotic perennial Carpobrotus edulis, and two native shrub species in California coastal scrub. American Journal of Botany 78: 885-894.

Davis, M.A. 2003. Biotic globalization: does competition from introduced species threaten biodiversity? Bioscience 53: 481-489.

Delgado-García, J.D. 2002. Interaction between introduced rats and a frugivore bird-plant system in a relict island forest. Journal of Natural History 36: 1247-1258. 
Doak, D.F., J.A. Estes, B.S. Halpern, U. Jacob, D.R. Lindberg, J. Lovvorn, D.H. Monson, M.T. Tinker, T.M. Williams, J.T. Wootton, I. Carroll, M. Emmerson, F. Micheli, and M. Novak. 2008. Understanding and predicting ecological dynamics: are major surprises inevitable? Ecology 89: 952-961.

Donlan, C.J., and C. Wilcox. 2008. Diversity, invasive species and extinctions in insular ecosystems. Journal of Applied Ecology 45: 1114-1123.

Dowding, J.E., E.C. Murphy, K. Springer, A.J. Peacock, and C.J. Krebs. 2009. Cats, rabbits, Myxoma virus, and vegetation on Macquarie Island: a comment on Bergstrom et al. Journal of Applied Ecology 46: 1129-1132.

Estoup, A., I.J. Wilson, C. Sullivan, J.M. Cornuet, and C. Moritz. 2001. Inferring population history from microsatellite and enzyme data in serially introduced cane toads, Bufo marinus. Genetics 159: 1671-1687.

Fukami, T., D.A. Wardle, P.J. Bellingham, C.P.H. Mulder, D.R. Towns, G.W. Yeates, K.I. Bonner, M.S. Durrett, M.N. Grant-Hoffman, and W.M. Williamson. 2006. Above- and below-ground impacts of introduced predators in seabird-dominated island ecosystems. Ecology Letters 9: 1299-1307.

Gaucel, S., and D. Pontier. 2005. How predator food preference can change the destiny of native prey in predator-prey systems. Biological Invasions 7: 795-806.

Gaze, P. 2000. The response of a colony of sooty shearwater (Puffinus griseus) and fleshfooted shearwater (P. carneipes) to the cessation of harvesting and the eradication of Norway rats (Rattus norvegicus). New Zealand Journal of Zoology 27: 375-379.

Gerber, G.P., and A.C. Echternacht. 2000. Evidence for asymmetrical intraguild predation between native and introduced Anolis lizards. Oecologia 124: 599-607.

Gillespie, R.G., E.M. Claridge, and G.K. Roderick. 2008. Biodiversity dynamics in isolated island communities: interaction between natural and human-mediated processes. Molecular Ecology 17: 45-57.

Girardet, S.A.B., C.R. Veitch, and J.L. Craig. 2001. Bird and rat numbers on Little Barrier Island, New Zealand, over the period of cat eradication 1976-80. New Zealand Journal of Zoology 28: 13-29.

Graham, M.F., and C.R. Veitch. 2002. Changes in bird numbers on Tiritiri Matangi Island, New Zealand, over the period of rat eradication. Pp. 120-123 in C.R. Veitch and M.N. Clout, eds. Turning the Tide: The Eradication of Invasive Species. IUCN SSC Invasive Species Specialist Group, IUCN, Gland, Switzerland and Cambridge, U.K.

Grant-Hoffman, M.N., and P.S. Barboza. 2010. Herbivory in invasive rats: criteria for food selection. Biological Invasions 12: 805-825.

Greenslade, P., M.I. Stevens, and R. Edwards. 2007. Invasion of two exotic terrestrial flatworms to subantarctic Macquarie Island. Polar Biology 30: 961-967.

Harper, G.A. 2005. Numerical and functional response of feral cats (Felis catus) to variations in abundance of primary prey on Stewart Island (Rakiura), New Zealand. Wildlife Research 32: 597-604.

Harper, G.A. 2007. Detecting predation of a burrow-nesting seabird by two introduced predators, using stable isotopes, dietary analysis and experimental removals. Wildlife Research 34: 443-453.

Harris, D. 2009. Review of negative effects of introduced rodents on small mammals on islands. Biological Invasions 11: 1611-1630.

Harris, D.B., and D.W. Macdonald. 2007. Interference competition between introduced black rats and endemic Galápagos rice rats. Ecology 88: 2330-2344. 
Holt, R.D. 1977. Predation, apparent competition, and the structure of prey communities. Theoretical Population Biology 12: 197-229.

Holt, R.D., and M.E. Hochberg. 2001. Indirect interactions, community modules and biological control: a theoretical perspective. Pp. 13-37 in E. Wajnberg, J.K. Scott, and P.C. Quimby, eds. Evaluating Indirect Ecological Effects of Biological Control. CAB International Publishing, Wallingford.

Holt, R.D., and J.H. Lawton. 1994. The ecological consequences of shared natural enemies. Annual Review of Ecology and Systematics 25: 495-520.

Howald, G.R., C.J. Donlan, J.P. Galván, J.C. Russell, J. Parkes, A. Samaniego, Y. Wang, C.R. Veitch, P. Genovesi, M. Pascal, A. Saunders, and B. Tershy. 2007. Invasive rodent eradication on islands. Conservation Biology 21: 1258-1268.

Hughes, B.J., G.R. Martin, and S.J. Reynolds. 2008. Cats and seabirds: effects of feral Domestic Cat Felis silvestris catus eradication on the population of Sooty Terns Onychoprion fuscata on Ascension Island, South Atlantic. Ibis 150: 122-131.

Kearns, C.A., D.W. Inouye, and N.M. Waser. 1998. Endangered mutualisms: the conservation of plant-pollinator interactions. Annual Review of Ecology and Systematics 29: $83-112$.

Kelly, D., A.W. Robertson, J.J. Ladley, S.H. Anderson, and R.J. McKenzie. 2006. The relative (un)importance of introduced animals as pollinators and dispersers of native plants. Pp. 227-245 in R. B. Allen and W. G. Lee, eds. Biological Invasions in New Zealand. Springer-Verlag, Berlin.

Krajick, K. 2005. Winning the war against island invaders. Science 310: 1410-1413.

Krivan, V. 1998. Effects of optimal antipredator behavior of prey on predator-prey dynamics: the role of refuges. Theoretical Population Biology 53: 131-142.

Krushelnycky, P.D., L.L. Loope, and N.J. Reimer. 2005. The ecology, policy, and management of ants in Hawaii. Proceedings of the Hawaiian Entomological Society 37: 1-25.

Kurle, C.M., D.A. Croll, and B.R. Tershy. 2008. Introduced rats indirectly change marine rocky intertidal communities from algae- to invertebrate-dominated. Proceedings of the National Academy of Sciences, USA 105: 3800-3804.

Lammers, T.G., and C.E. Freeman. 1986. Ornithophily among the Hawaiian Lobelioideae (Campanulaceae): evidence from floral nectar sugar compositions. American Journal of Botany 73: 1613-1619.

Le Corre, M. 2008. Cats, rats and seabirds. Nature 451: 134-135.

McChesney, G.J., and B.R. Tershy. 1998. History and status of introduced mammals and impacts to breeding seabirds on the California Channel and Northwestern Baja California islands. Colonial Waterbirds 21: 335-347.

Moles, A.T., and D.R. Drake. 1999. Post-dispersal seed predation on eleven large-seeded species from the New Zealand flora: a preliminary study in secondary forest. New Zealand Journal of Botany 37: 679-685.

Nogales, M., A. Martín, B.R. Tershy, C.J. Donlan, D. Veitch, N. Puerta, B. Wood, and J. Alonso. 2004. A review of feral cat eradication on islands. Conservation Biology 18: 310-319.

O'Connor, N.E., and T.P. Crowe. 2005. Biodiversity loss and ecosystem functioning: distinguishing between number and identity of species. Ecology 86: 1783-1796.

O’Dowd, D.J., P.T. Green, and P.S. Lake. 2003. Invasional 'meltdown' on an oceanic island. Ecology Letters 6: 812-817. 
Olesen, J.M., L.I. Eskildsen, and S. Venkatasamy. 2002. Invasion of pollination networks on oceanic islands: importance of invader complexes and endemic super generalists. Diversity and Distributions 8: 181-192.

Orrock, J.L., R.D. Holt, and M. Baskett. 2010. Refuge-mediated apparent competition in plant-consumer interactions. Ecology Letters 13: 11-20.

Pain, D.J., M.d.L. Brooke, J.K. Finnie, and A. Jackson. 2000. Effects of brodifacoum on the land crab of Ascension Island. Journal of Wildlife Management 64: 380-387.

Paine, R.T., J.T. Wootton, and P.D. Boersma. 1990. Direct and indirect effects of peregrine falcon predation on seabird abundance. Auk 107: 1-9.

Parrish, J.K., R.T. Paine, and M. Marvier. 2001. Direct and indirect effects: interactions between bald eagles and common murres. Ecological Applications 11: 1858-1869.

Peck, D.R., L. Faulquier, P. Pinet, S. Jaquemet, and M.L. Corre. 2008. Feral cat diet and impact on sooty terns at Juan de Nova Island, Mozambique Channel. Animal Conservation 11: 65-74.

Persson, L. 1985. Asymmetrical competition: are larger animals competitively superior? The American Naturalist 126: 261-266.

Pierce, R. J. 2002. Pacific rats: their impacts on two small seabird species in the Hen and Chicken Islands, New Zealand. Pp. 410 in C.R. Veitch and M.N. Clout, eds. Turning the Tide: The Eradication of Invasive Species. IUCN SSC Invasive Species Specialist Group, IUCN, Gland, Switzerland and Cambridge, U.K.

Polis, G.A., C.A. Myers, and R.D. Holt. 1989. The ecology and evolution of intraguild predation: potential competitors that each other. Annual Review of Ecology and Systematics 20: 292-330.

Prugh, L.R., C.J. Stoner, C.W. Epps, W.T. Bean, W.J. Ripple, A.S. Laliberte, and J.S. Brashares. 2009. The rise of the mesopredator. Bioscience 59: 779-791.

Quillfeldt, P., I. Schenk, R.A.R. McGill, I.J. Strange, J.F. Masello, A. Gladbach, V. Roesch, and R.W. Furness. 2008. Introduced mammals coexist with seabirds at New Island, Falkland Islands: abundance, habitat preferences, and stable isotope analysis of diet. Polar Biology 33: 333-349.

Rayner, M.J., M.E. Hauber, M.J. Imber, R.K. Stamp, and M.N. Clout. 2007. Spatial heterogeneity of mesopredator release within an oceanic island system. Proceedings of the National Academy of Sciences, USA 104: 20862-20865.

Riera, N., A. Traveset, and O. García. 2002. Breakage of mutualisms by exotic species: the case of Cneorum tricoccon L. in the Balearic Islands (Western Mediterranean Sea). Journal of Biogeography 29: 713-719.

Risbey, D.A., M.C. Calver, and J. Short. 1999. The impact of cats and foxes on the small vertebrate fauna of Heirisson Prong, Western Australia. I. Exploring potential impact using diet analysis. Wildlife Research 26: 621-630.

Robertson, A.W., D. Kelly, J.J. Ladley, and A.D. Sparrow. 1999. Effects of pollinator loss on endemic New Zealand mistletoes (Loranthaceae). Conservation Biology 13: 499-508.

Rodríguez, C., R. Torres, and H. Drummond. 2006. Eradicating introduced mammals from a forested tropical island. Biological Conservation 130: 98-105.

Roemer, G.W., C.J. Donlan, and F. Courchamp. 2002. Golden eagles, feral pigs, and insular carnivores: how exotic species turn native predators into prey. Proceedings of the National Academy of Sciences, USA 99: 791-796.

Roy, S., G.C. Smith, and J.C. Russell. 2009. The eradication of invasive mammal species: can adaptive resource management fill the gaps in our knowledge? Human-Wildlife Conflicts 3: 30-40. 
Ruffino, L., K. Bourgeois, E. Vidal, J. Icard, F. Torre, and J. Legrand. 2008. Introduced predators and cavity nesting seabirds: unexpected low level of interaction at breeding sites. Canadian Journal of Zoology 86: 1068-1073.

Ruscoe, W.A., G. Norbury, and D. Choquenot. 2006. Trophic interactions among native and introduced animal species. Pp. 247-263 in R.B. Allen and W.G. Lee, eds. Biological Invasions in New Zealand. Springer-Verlag, Berlin.

Savidge, J.A. 1987. Extinction of an island forest avifauna by an introduced snake. Ecology 68: 660-668.

Schoener, T.W., and D.A. Spiller. 1996. Devastation of prey diversity by experimentally introduced predators in the field. Nature 381: 691-694.

Schoener, T.W., and D.A. Spiller. 1999. Indirect effects in an experimentally staged invasion by a major predator. American Naturalist 153: 347-358.

Schoener, T.W., D.A. Spiller, and J.B. Losos. 2001. Predators increase the risk of catastrophic extinction of prey populations. Nature 412: 183-186.

Sears, A.L.W., R.D. Holt, and G.A. Polis. 2004. Feast and famine in food webs: the effects of pulsed productivity. Pp. 359-386 in G.A. Polis, M.E. Power, and G.R. Huxel, eds. Food Webs at the Landscape Level. University of Chicago Press, Chicago.

Sih, A., G. Englund, and D. Wooster. 1998. Emergent impacts of multiple predators on prey. Trends in Ecology and Evolution 13: 350-355.

Simberloff, D. 2003. How much information on population biology is needed to manage introduced species? Conservation Biology 17: 83-92.

Simberloff, D., and B. Von Holle. 1999. Positive interactions of nonindigenous species: invasional meltdown? Biological Invasions 1: 21-32.

Spiller, D.A., and T.W. Schoener. 2001. An experimental test for predator-mediated interactions among spider species. Ecology 82: 1560-1570.

Taylor, R.H. 1979a. How the Macquarie Island parakeet became extinct. New Zealand Journal of Ecology 2: 42-45.

Taylor, R.H. 1979b. Predation of sooty terns at Raoul Island by rats and cats. Notornis 26 : 199-202.

Towns, D.R. 1991. Response of lizard assemblages in the Mercury Islands, New Zealand, to removal of an introduced rodent: the kiore (Rattus exulans). Journal of The Royal Society of New Zealand 21: 119-136.

Towns, D.R., I.A.E. Atkinson, and C.H. Daugherty. 2006. Have the harmful effects of introduced rats on islands been exaggerated? Biological Invasions 8: 863-891.

Traveset, A., M. Nogales, J.A. Alcover, J.D. Delgado, M. López-Darias, D. Godoy, J.M. Igual, and P. Bover. 2009. A review on the effects of alien rodents in the Balearic (Western Mediterranean Sea) and Canary Islands (Eastern Atlantic Ocean). Biological Invasions 11: 1653-1670.

Traveset, A., and D.M. Richardson. 2006. Biological invasions as disruptors of plant reproductive mutualisms. Trends in Ecology and Evolution 21: 208-216.

Williams, P.A., B.J. Karl, P. Bannister, and W.G. Lee. 2000. Small mammals as potential seed dispersers in New Zealand. Austral Ecology 25: 523-532.

Wootton, J.T. 1994. The nature and consequences of indirect effects in ecological communities. Annual Review of Ecology and Systematics 25: 443-466.

Zavaleta, E.S., R.J. Hobbs, and H.A. Mooney. 2001. Viewing invasive species removal in a whole-ecosystem context. Trends in Ecology and Evolution 16: 454-459.

Zhang, J., M. Fan, and Y. Kuang. 2006. Rabbits killing birds revisited. Mathematical Biosciences 203: 100-123. 
